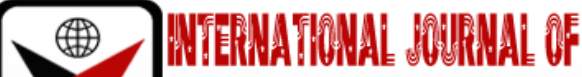

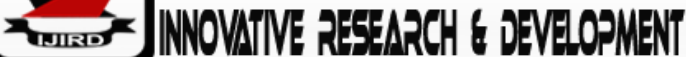

ISSN 2278-0211 (Online)

\section{Corporate Governance and Implementation of Financial Management Practices in Financial Institutions of the Federal Government of Somalia}

\author{
Abdikadir Abdullahi Ali \\ Ph.D. Candidate, Department of Financial/Mgt Strategy Consultancy, \\ ALI-BOY Association, Kenya \\ Thomas Anyanje Senaji \\ Professor, Department of Academics and Students Affairs, \\ The East African University, Kenya \\ Dr. Douglus Ogolla Awino \\ Senior Lecturer, Department of Business Administration, \\ Kenya Methodist University, Kenya
}

\begin{abstract}
:
Effective implementation of financial management practices by government institutions has important implications for delivery of service to citizens. However, some reports indicate the need for improvement of these practices in the Federal Government of Somalia though corporate governance can partly address this concern. The purpose of this study was to examine the relationship between corporate governance and implementation of financial management practices in financial Institutions of the Federal Government of Somalia. A descriptive quantitative survey of 112 respondents was conducted using self-report structured questionnaires. The results indicated that there was inadequate compliance with the four corporate governance principles, namely participation, accountability, transparency and equity, because the responses had a mean of three $(M=3)$ on a scale of 1 to 5 where $1=$ strongly disagree and 5=strongly agree with statements of the practice of the principle. Further, there was insufficient implementation of financial management best-practices of planning, control, budgeting and resource allocation. It was also established that corporate governance practices had a significant influence on the implementation of financial management practices. Two of corporate governance principles, transparency and accountability, were found to be significant predictors of implementation of financial management practices. The influence of participation and equity principles of corporate governance were not significant at 5\% level of significance (both $p$-values were greater than 0.05). These findings provide policy implications for the Federal Government of Somalia institutions for enhancing their corporate governance practices which would lead to improvement in the implementation of bestpractice financial management practices
\end{abstract}

Keywords: Corporate governance, financial management practices, financial institutions, federal government

\section{Introduction}

Financial institutions have always been some of the most important sectors of the government. It is the cornerstone of socio-economic development of the society and the nation at large. In this regard, the performance of financial institutions is of interest of organisations of all types including governments and the role of corporate governance in ensuring satisfactory performance of financial institutions continues to attract empirical examination.

Corporate governance is a concept that captures two key concepts, that is, corporate and governance. Corporate implies institutional or that which pertains to institutions or firms. On the other hand, governance refers to the manner in which power is executed in the management of economic and social resources with the object of realizing sustainable human development. Corporate governance is the global phenomenon related with the pattern towards more prominent corporate duty and the direct of business inside worthy moral guidelines. Straightforwardness, responsibility and receptiveness in announcing and exposure of information, both operational and budgetary, are globally acknowledged to be crucial to the act of corporate governance techniques. The object of good corporate governance is accomplished when Organisations exhibit their open responsibility and direct their business within moral models. The result of this will appear as powerful financial performance results, both internally and externally (Fourier, 2006). For government offices, this gets apparent in governance practice whose effect shows in progress in 
the financial advancement practices, general way of life, poverty decrease, alleviation of imbalances in pay dispersion, and improvement in the general prosperity of its residents (Kusumasari, Alam\&Siddiqui, 2010).

Corporate governance has been instrumental in bolstering the image of institutions. It has also facilitated efficient, effective and sustainable institution, which has resulted in providing solutions to emerging challenges including financial challenges. Corporate governance has also been credited for ensuring that institutions are both responsive and accountable. However, there is scarcity of empirical evidence on the relationship between corporate governance and financial management practices in financial institutions of the Federal government of Somalia (FGS). It is on this premise that this study was conducted to determine the relationship between the adoptions of four corporate government principles: participation, transparency, accountability, and equity and implementation of financial management practices, namely planning, control, budgeting and resource allocation.

Somalia has reliably been positioned among the world's most degenerate nations in Transparency International's Corruption Perceptions Index, since the nation was first presented in this position in 2007/8. In 2013, Somalia scored eighth exceptionally degenerate (Transparency International, 2013). As indicated by the Somalia Public Service commission report (2013), debasement has been showed in gift, misappropriation, misrepresentation, coercion, and maltreatment of intensity, irreconcilable circumstance, preference, nepotism and burglary in type of intrigue. Be that as it may, the top governance organization ought to be 'multifaceted' (Capon, 2001) and basic leadership is nevertheless one of its various jobs (Guesalaga\&Johnston, 2010). Along these lines, top governance organization may prompt irreconcilable situation in their supervision of the boards and management. These can be seen from the open financial related governance self-evaluation report that was made and which uncovered ineffective parliamentary oversight over open budgetary governance capacities, absence of complete giving an account of the utilization of state assets and the nonappearance of a really free reviewer general (Federal Republic of Somalia, 2013). It is hence in this way that a need emerged to conduct an examination of corporate governance practicesand execution of financial managementin budgetary institutions of Federal Government of Somalia to determine whether there is a significant relationship between corporate governance and financial governance.

\section{Theory and Hypothesis}

From the forgoing discussion, corporate administration is a perfect, which is hard to accomplish in its totality. Not many nations and social orders have verged on accomplishing great corporate administration in its totality. Relying on the Upper Echelons Theory (UE)that spreads the organization's behaviour, including how well its strategy is implemented, is a reflection of senior management's thinking and action. It is reasonable to note that corporate governance exercised by senior managers and the Board of Directors has a significant impact on the implementation of financial management practices. Studies have been done concerning corporate governance issues and financial management. For example, Knell (2006) and Cadbury (1992) present corporate governance as frameworks, organized procedures, characterized approaches and establishments that impact the manner in which a foundation is coordinated, regulated or controlled. It fuses associations among head players, for instance, speculators, the officials and the directorate while seeing the targets for which the organization is spoken to and associations among various accomplices including suppliers, customers, agents, banks and distinctive advance experts, controllers the earth and network on the loose. Corporategovernance controls are intended to support the productive utilization of assets and advance responsibility for the stewardship of assets utilized by administrators (Cadbury, 2000). The ongoing worldwide spate of organizations utilizing false bookkeeping strategies to cover declining financial related conditions has pulled in the consideration of controllers and bookkeepers. The U.S. government reacted to the corporate embarrassments with the Sarbanes-Oxley Act in January 2002.

Corporate administration is a ton of criteria that strengthen straightforwardness, dependability, sensibility, duty and commitment in legitimate administration (Cadbury, 2002). Also, corporate administration is a great deal of rules, administrative standards, structures, methods, social orders and systems, which achieves achieving obligation, straightforwardness, sensibility, reliability and in regards to the benefits of accomplices (Eccles and DiPiazza, 2002). As it were, in corporate governance, while the objectives of the business visionary, including the investors' advantages, are acquired, the premiums of partners are additionally fulfilled, and the association's exercises and checking methods are set up so that the rightness and legality of the activity are likewise kept up (Bushman et al., 2004). (Damodaran, 2007) Transparency of the assignments and information presentation is among the key and focal parts of corporate administration (Carse, 2000). Thus, the models of corporate administration and open disclosure are known as the interrelated segments in watching the affiliation's exercises. On the other hand, mistaken and non-direct information can unequivocally and oppositely sway on the budgetary markets robustness. To achieve straightforwardness in the organization's exercises, it is required to apply the inward control structure to accomplish a major sureness about budgetary reports and about their consistence with the related rules. As such, the proficiency of the association can be accomplished. Therefore, by adopting the related principles of corporate governance will ensure governance transparency, accountability, participation and equity on information disclosure is proposed, which can be used for effective implementation of the governance management strategy (Bidabad, 2012). This strategy comprises effective practice of planning, control, budgeting and resource allocation to programmes and projects that are intended to ensure sustainable development. Financial related governance is worried about governance of incomes into and out of the firm; budgetary governance inside the firm and the board of financial adjusts held by the firm - deficiency financing or contributing surplus financial. Financial related governance attempts to achieve at least cost the different errands of financial assortment, instalment of exceptional and orchestrating shortage financing or surplus speculation (Sloan,2001). 
As demonstrated by Wanyama (2013) the money related plans and the spending strategy can be seen as the motivation behind departure for careful, direct and dependable open division monetary related administration. The Public Governance Management Act (PFMA) requires that these plans, which are reflecting the administration needs with respect to administration movement, are deferred in Parliament and are made open after the spending talk of the Minister of Finance. Notwithstanding the way that the PFMA system approves straightforwardness and obligation, there are still shortcomings in choosing if the assignments by workplaces and state components are doubtlessly watching out for national needs and offering some motivator for financial yields. In the chief event the specific thought of the plans can understand confusion the cognizance of the game plan and afterward again the costing strategy isn't clearly indisputable or available (Sloan, 2001). While the instruments are set up, for instance, the masterminding and uncovering technique to parliament and parliamentary board, the specific competency of such associations to totally respect the manner in which where open resources are directed ought to be improved to ensure extraordinary governance.

The improvement can be practiced by drawing on commitments from interest get-togethers, scholastics, normal society and even through gatherings with private portion fitness to audit the plans and confirm the costing technique. This will consider government specialists mindful with respect to ensuring practicality, viability and productivity. Therefore, implementation of governance management practices is significant for understanding the certainty of governance institutions of the FGS to decide which approach to move forward when designing a strategy to strengthen employee participation, governance information transparency, and accountability, and equity to improve implementation of governance management.

Based on the reviewed literature, the relationship between the study variables is shown in Figure 1, which suggests that corporate governance variables namely, Participation, Transparency, Accountability and Equity influence on implementation of governance management practices.

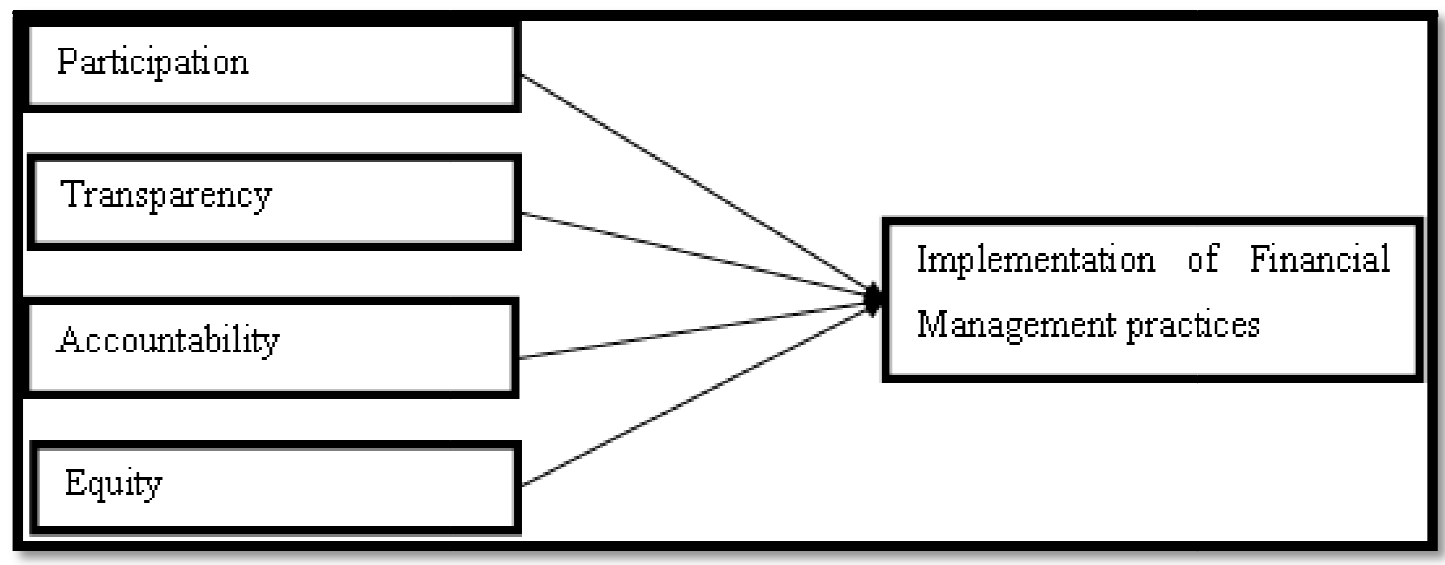

Figure 1: Conceptual Framework

An examination of the relationship between corporate governance and implementation of governance management practices; and how governance institutions of the Federal Government of Somalia practice the corporate governance principles mentioned in the conceptualization measurement can increase our understanding of the relationship between the two phenomena: corporate governance principles and implementation of governance management practices. We next present four hypotheses that were tested in this study.

- $\mathrm{H}_{1}$ : Participation has no significant influence on implementation of financial management in financial institutions in the federal government of Somalia.

- $\mathrm{H}_{2}$ : Transparency has no significant influence on implementation of financial management in financial institutions in the federal government of Somalia.

- $\mathrm{H}_{3}$ : Accountability has no significant influence on implementation of financial management in financial institutions in the federal government of Somalia.

- $\mathrm{H}_{4}$ : Equity has no significant influence on implementation of financial management in financial institutions in the federal government of Somalia.

\section{Methodology}

The study used a descriptive co-relational survey design; the investigation additionally utilized a cross sectional, relative and ex-post facto designs and was pursued a quantitative worldview. Descriptive design investigation that information gathered was utilized to depict a marvel; co-social in that it was keen on relating corporate governance and financial governance rehearses and that relevant information was gathered from the respondents once and to lessen on schedule and costs required on such a huge populace. Near, in that the investigation decided if there is a huge contrast in the degree of corporate governance and financial governance rehearses in some chose financial related Institutions of the Federal Government of Somalia. Ex-post facto since the scientist has no influence over the factors and just tries to report what's going on in the field. The examination additionally adopted a quantitative strategy in that it depended on factors estimated with numbers and broke down with measurable methods. The examination depended on since it included an enormous example (Creswell, 2003; Kahn, 1993; Kothari, 2004). 
In this investigation, the objective populace was 155 representatives of the chosen Governance Institutions of the Federal Government of Somalia. Every one of the classes of workers (top level chiefs, middle level administrators, and lower level supervisors) were included since they are legitimately influenced by the approach made on corporate governance and budgetary governance.

Given that the target population is 155 employees (which was included 65 Finance Ministry, 22 Audit General, 18 Central bank of Somalia, 16 Accountant General and 34 other governance departments of the rest ministries) a sample of 112 respondents was used. Stratified random sampling was utilized for choosing of the example to diminish costs, time of doing research and to build the level of precision of the investigation, (Saunders et al, 2000). As to estimate, the testing outlines (for example representatives) in the chose governance related Institutions was stratified by divisions in each of the governance Institutions of the FGS. At that point proportionate arbitrary examples were looked over the particular strata (Creswell, 2003).

\section{Results and Discussion}

Zero-order correlation was conducted for the principles of corporate governance and implementation of governance management practices in Public Sector using bivariate correlations; the results are reported in Table 3.

\begin{tabular}{|c|c|c|c|c|c|c|c|c|}
\hline No & Variables & Mean & $\begin{array}{c}\text { Standard } \\
\text { Deviation }\end{array}$ & $\mathbf{1}$ & $\mathbf{2}$ & $\mathbf{3}$ & $\mathbf{4}$ & $\mathbf{5}$ \\
\hline 1 & Participation & 3.15 & 1.329 & 1 & & & & \\
\hline 2 & Transparency & 3.03 & 1.391 & .736 & 1 & & & \\
\hline 3 & Accountability & 3.32 & 1.327 & .744 & .715 & 1 & & \\
\hline 4 & Equity & 3.10 & 1.294 & .725 & .539 & .527 & 1 & \\
\hline 5 & $\begin{array}{c}\text { Financial management } \\
\text { practices }\end{array}$ & 3.29 & 1.399 & .651 & .677 & .737 & .580 & 1 \\
\hline
\end{tabular}

Table 3: Relationship between Corporate Governance Practices and

Implementation of Financial Management in Financial Institutions

As shown in Table 3, the implementation of financial management practices and corporate governance principles namely; Participation, transparency, accountability and equity. Moreover, financial management practices were significantly correlated with participation $(\mathrm{r}=.651, \mathrm{p}<.05)$, transparency $(\mathrm{r}=.725, \mathrm{p}<.05)$, accountability $(\mathrm{r}=.744, \mathrm{p}<.05)$, and equity with $(\mathrm{r}=.736, \mathrm{p}<.05)$. So, there were significant relationships among all principles of corporate governance with governance management practices, highest association reported between accountability and governance management practice, this explains the improvement of governance management system, the federal government totally use online system which improved the accountability $(\mathrm{r}=.737, \mathrm{p}<.05)$. Second highest correlation score reported were between transparency with dependent variable, $(\mathrm{r}=.677, \mathrm{p}<.05)$. Equity had significant positive and moderate relationship with governance management practices $(\mathrm{r}=.580, \mathrm{p}<.05)$. Participation principle recorded that their significant moderate association with implementation of governance management practices.

Multiple linear regression analysis was used to test the influence of corporate governance principles (participation, transparency, accountability, and equity) on implementation of governance management practices; the result is presented in Table 4.

\begin{tabular}{|c|c|c|c|c|}
\hline Variables & Beta & t-test & p-value & Remarks \\
\hline Participation & .059 & .5310 & .597 & $\mathrm{H}_{1}:$ Rejected \\
\hline Transparency & .220 & 2.369 & .020 & $\mathrm{H}_{2}:$ Accepted \\
\hline Accountability & .471 & 4.991 & .000 & $\mathrm{H}_{3}$ : Accepted \\
\hline Equity & .155 & 1.809 & .073 & $\mathrm{H}_{4}:$ Rejected \\
\hline R Square & .637 & & & \\
\hline
\end{tabular}

Table 4: Regression Coefficients

For the influence of participation and implementation of governance management practices $\left(\mathrm{H}_{1}\right)$, the regression analysis result in Table 4 indicates that implementation of employee participation corporate governance principle in the governance institution of the FGS did not have a significant influence on governance management practices $(\beta=.059$, $\mathrm{t}=.531, \mathrm{p}=.597>.05)$. This finding led to rejection of $\mathrm{H}_{1}$. Also the below table shows that Equity has no influence on governance management practices in federal government of Somalia $(\beta=.155, t=1.809, p=.073>.05)$ therefore $\mathrm{H}_{4}$ were rejected. Transparency principle clearly shows in table 4 that it has positive significance relationship with the dependent variable $(\beta=.220, t=2.369, p=.020<.05)$ therefore, $\mathrm{H}_{2}$ was supported. Further, the accountability principle had significant effect on the implementation of governance management practices $(\beta=.471, t=4.991, p<.001)$ therefore the $\mathrm{H}_{3}$ were accepted.

The results of Step-wise regression analysis suggested that accountability principle of public governance institution $\left(\mathrm{R}^{2}=.471\right)$ was the best predictor of the governance management practices. This means if governance institutions in Somalia focused and invested on accountability measurement this will contribute to the performance of governance practices in the country. All the corporate governance principles $\left(\mathrm{R}^{2}=.637\right)$ managed to explain around $64 \%$ of variance in the criterion variable (governance management practices). 


\section{Conclusion}

All organizations including government formulate strategies to achieve their vision. However, for effective leadership required guiding government strategies for development programs, these resources are used to ensure that governance resources are allocated according to best practices. Relying on the Upper Echelons Theory (UE)that spreads the organization's behaviour, including how well its strategy is implemented, is a reflection of senior management's thinking and action. It is reasonable to note that corporate governance exercised by senior managers and the Board of Directors has a significant impact on the implementation of governance management practices. This section is discussion of the major findings of the study and relates to the findings of previous studies when it possible. This study was aimed at determination of the relationship between four corporate governance principles namely, participation, transparency, accountability and equity and implementation of governance management practices by the governance institutions of the Federal Government of Somalia. The objectives of this study were first, to determine the extent of implementation of four corporate governance principles (participation, transparency, accountability and equity) in governance institutions of the Federal Government of Somalia; secondly, to explore the implementation of financial management practices in the financial governance institutions of government, and thirdly, to examine the relationship between corporate governance principles and implementation of financial managementin the financial governance institution of the Federal Government of Somalia.

Data were collected from selected financial governance institution of the Federal Government of Somalia in Mogadishu; these were; Ministry of Finance, Audit general, Central bank, Accountant General and other the governance departments of remaining ministries. Data were collected from 112 respondents. First we examined the data for normal distribution using skewness and kurtosis and result showed that the distribution of the collected data approximated normality distribution hence the use of linear regression to examine the relationship between adoption of corporate governance principles and implementation of governance management practices.

Further analysis took place, to test the relationship between the variables; researcher utilized bivariate correlations to determine the interrelationships of the variables. The researcher developed five hypotheses to test the linear relationships; two hypotheses were rejected as suggested the findings because of law P-value which means insignificance association between participation and equity principles with governance management practices. The results of the tested hypotheses illustrated that $\left(\mathrm{H}_{2}\right.$, and $\left.\mathrm{H}_{3}\right)$ were fully supported while $\mathrm{H}_{1}$ and $\mathrm{H}_{4}$ were rejected in the model.

This study examined the relationship between adoption of corporate governance principles and implementation of governance management practices using different indicators, as results of the regression analysis reported that two of corporate governance found to be significant predictor of dependent variable. These results were supporting past studies on the topic as transparency and accountability is generally seen as an impetus toward governance management practices and growth, at least within certain contexts, has been shown to be positively associated with, or as having a positive impact on governance management practices.

\section{Recommendations}

As far as suggestions, the most significant one is routed to the upgrade of the corporate governance standards in the budgetary foundations particularly in the government of Somalia going along completely with the open division standards and financial related directions standards. Furthermore, visit checking apparatuses for controlling the use of such standards in the legislature ought to be set up. The way that Somalia is a creating nation and with shakiness in governance and weakness issues is progressively delicate and hard to be observed and hence financial related governance rehearses in financial organizations is critical to give the nation budgetary stream to significant segments of the economy for advancement to be figured it out.

In addition, governance institutions themselves must be increasingly cautious on specific issues like duality and inward control capacities. Superior practice of transparency and responsibility is required. The dynamic parts of corporate governance change are not yet fully known. An examination of hidden political economy factors that may drive changes in the lawful systems and frameworks of governance related establishments after some time is fundamental and can provide more insights to the understanding of the relationship between corporate governance practices and implementation of financial management practices. Later on Government of Somalia ought to accomplish more in the field of corporate governance, particularly when financial emergency requires governance organizations to address the awkward nature in the economy.

\section{References}

i. Amin, M. E. (2005) Social Science Research: conception, methodology andanalysis.Kampala, Uganda:Makerere University Press.

ii. Beal, F. M. (2008). Double jeopardy:To be Black and female. Meridians, 8(2), 166- 176.

iii. DiPiazza, S. A., \& Eccles, R. G. (2002). Building Public Trust. Wiley

iv. Bidabad, B. (2012). Foreign policy principles: An Islamic Sufi Approach - Part I. 54. 97-124. $10.1108 / 17542431211208531$.

v. Cadbury, A. (1992). Cadbury report: The financial aspects of corporate governance. Tech report, HMG, London.

vi. Creswell, J. W. (2003). Research design: Qualitative, quantitative, and mixed methods approach (2nd ed.). Thousand Oaks, CA: Sage.

vii. Damodaran, A. (2007) Valuation Approaches and Metrics: A Survey of the Theory and Evidence. Hanover: Now Publishers. 
viii. Fourier, D. (2006). Good Governance in ensuring sound public governance management. University Pretoria. Lecture paper

ix. Guesalaga, R., \& Johnston, W. (2010). What's next in key account management research? Building the bridge between the academic literature and the practitioners' priorities. Industrial Marketing Management, 39(7), 1063-1068.

x. Knell, M., Köhler-Töglhofer, W., \&Prammer, D. (2006). The Austrian pension system-How recent reforms have changed fiscal sustainability and pension benefits. Monetary Policy \& the Economy Q, 2, 69-93.

xi. Kusumasari, B., Alam, Q., \& Siddiqui, K. (2010). Resource Capability for Local Government in managing disaster. Disaster Prevention and Management. An International Journal,13 (8) 96-120.

xii. Saunders, M., Lewis, P., \&Thornhill, A. (2000). Research Methods for Business Students, 4ed. Prentice Hall.

xiii. Sloan, R. G. (2001) Governance Accounting and Corporate Governance: A Discussion USA

xiv. Wanyama, W.D. (2013). Effects of Corporate Governance on Financial Performance of Listed Insurance Firms in Kenya. Public Policy and Administration Research ISSN 2224-5731(Paper) ISSN 2225-0972(Online) 13 